\title{
Dengue-yellow fever sera cross-reactivity; challenges for diagnosis
}

\section{Reacción cruzada en sueros de Fiebre Amarilla y Dengue: Desafíos para el diagnóstico}

\author{
Natalia Houghton-Triviño ${ }^{1}$, Diana Montaña ${ }^{1}$ and Jaime E. Castellanos ${ }^{1,2}$ \\ 1 Instituto de Virología, Universidad El Bosque, Bogota, Colombia. \\ castellanosjaime@unbosque.edu.co \\ 2 Grupo Patogénesis Viral, Facultad de Odontología, Universidad Nacional de Colombia, \\ Bogota, Colombia
}

Recibido 18 Septiembre 2007/Enviado para Modificación 29 Marzo 2008/Aceptado 8 Abril 2008

\begin{abstract}
Objective The Flavivirus genera share epitopes inducing cross-reactive antibodies leading to great difficulty in differentially diagnosing flaviviral infections. This work was aimed at evaluating the complexity of dengue and yellow fever serological differential diagnosis.

Material and methods Dengue antibody capture ELISA and a yellow fever neutralisation test were carried out on 13 serum samples obtained from yellow fever patients, 20 acute serum samples from dengue patients and 19 voluntary serum samples pre- and post-vaccination with YF vaccine.

Results Dengue ELISA revealed IgM reactivity in $46,2 \%$ of yellow fever patients and $42 \%$ of vaccinees. Sixteen out of 20 dengue patients (80 \%) had high YF virus neutralisation titres.

Conclusions. Such very high cross-reactivity data challenged differential laboratory diagnosis of dengue and yellow fever in areas where both flaviviruses co-circulate. New laboratory strategies are thus needed for improving the tests and providing a specific laboratory diagnosis. Cross-reactivity between Flaviviruses represents a great difficulty for epidemiological surveillance and preventing dengue, both of which demand urgent attention.
\end{abstract}

Key Words: Dengue, yellow fever, flavivirus, differential diagnosis (source: MeSH, $N L M)$.

\section{RESUMEN}

Objetivo Los miembros del genero Flavivirus poseen epítopes inductores de anticuerpos de reactividad cruzada, lo que representa una gran dificultad en el diagnostico diferencial. En este trabajo nos propusimos evaluar la complejidad del diagnostico diferencial entre dengue y fiebre amarilla. 
Materiales y métodos Ensayos de ELISA de captura para dengue y de neutralización para fiebre amarilla fueron realizados en 13 muestras de suero de pacientes con fiebre amarilla, 20 muestras de pacientes con dengue en fase aguda y 19 voluntarios sanos antes y después de ser vacunados para la fiebre amarilla.

Resultados Los ensayos de ELISA para IgM contra dengue mostraron reactividad cruzada en el $46,2 \%$ de los pacientes con fiebre amarilla y $42 \%$ de los vacunados. Dieciséis de los 20 pacientes con Dengue (80 \%) tuvieron altos títulos de anticuerpos neutralizantes para fiebre amarilla.

Conclusión La alta reactividad cruzada que se encontró, representa un desafío para el diagnostico diferencial del dengue y fiebre amarilla en áreas donde co-circulan estos Flavivirus. Nuevas estrategias de diagnóstico de laboratorio son necesarias para suministrar un diagnóstico especifico. La reactividad cruzada entre Flavivirus representa un gran problema para la vigilancia epidemiológica, control y prevención del dengue, el cual debe ser solucionado.

Palabras Clave: Dengue, Fiebre Amarilla, Flavivirus, diagnóstico diferencial (fuente: DeCS, BIREME).

$\mathrm{D}$ engue virus (DENV) and yellow fever virus (YFV) are arboviruses belonging to the Flaviviridae family (Flavivirus genus). These have led to strong epidemiological surveillance programmes being developed which are focused on rapid, accurate laboratory diagnosis for the early implementation of specific preventative health measures for curtailing outbreaks and reducing disease burden (1). Laboratory diagnosis of infection depends on detecting specific DENV and YFV host antibodies. Neutralisation assays are considered to provide the greatest specificity from all currently available serological methods (2). However, the enzyme immunoassay (ELISA) is the most commonly used method because of its low cost and the speed of its results; it has also been reported to be a highly specific assay (3), although this could be difficult in flavivirus serology.

Cross-reactive antibody responses to antigenic epitopes common to all flaviviruses on envelope (E) protein may, however, pose an important problem in serological diagnosis in areas where multiple flaviviruses circulate (4). Such shared epitopes induce cross-reactivity and may also lead to a dramatic increase in the severity of secondary infections via antibody-dependent enhancement, particularly in the case of DENV serotypes.

DENV and YFV are endemic diseases in Colombia (5). An average 50000 annual dengue fever cases have been reported in Colombia since 2000; an 
average of 4500 dengue haemorrhagic fever (DHF) cases have been reported during this period, this being around $30 \%$ of the DHF burden in America (6). One of the largest sylvatic YFV outbreaks in Colombia's history was reported in 2003, involving 112 cases leading to 50 deaths. Colombia is considered to be a country having a high risk of urban yellow fever epidemics due to ubiquitous Aedes aegypti infestation; mass YF vaccination is therefore frequent.

Despite the neutralisation test being the gold standard for flavivirus serology, DENV and YFV surveillance is based on detecting specific IgM and IgG antibodies by ELISA. The existence of cross-reactivity may thus pose a real challenge for sero-epidemiological studies and routine case confirmation of both entities. However, it is not known whether rapid, specific differential DENV and YFV infection diagnosis is possible in countries having limited resources or whether new experimental strategies should be designed. Accordingly, this study was aimed at evaluating the effect of cross-reactive serum antibodies in widely-used commercial UMELISA assays in Colombia for diagnosing DENV and YFV neutralisation assays (7).

\section{MATERIALS AND METHODS}

Seventy-one serum samples were evaluated from patients infected by DENV or YVF and from healthy volunteers. The samples came from different parts of Colombia; 13 from YF patients involved in the 2003 outbreak in Santa Marta (which were confirmed by epidemiology, serology or histopathology), 20 patients from the Huila department having clinical and laboratory confirmation of dengue and who did not have a YF vaccination history and 19 YFV (Stamaril Pasteur Lot 5596-1) pre- and post-vaccination (21 days) serum samples from healthy individuals living in Bogotá, Colombia, who had not been previously vaccinated and whose anamnesis did not report dengue. All sera were stored at $-20 \mathrm{oC}$ until testing. Blood samples were drawn from volunteers after they had signed a written consent-form. The patients' serum samples were used for routine diagnosis during outbreaks. All the procedures described had been previously approved by the Universidad El Bosque Ethics' Committee, in line with Colombian Ministry of Health Resolution 8430/1993.

Vero cells were cultured in plastic tissue flasks in Dulbecco's modified Eagle medium (DMEM), supplemented with $10 \%$ foetal bovine serum (FBS, Clontech), antibiotics (100 U/ml penicillin and $100 \mathrm{~g} / \mathrm{ml}$ streptomycin) and 0,25 $\mathrm{g} / \mathrm{ml}$ amphotericin (GIBCO) at $37^{\circ} \mathrm{C}$ in a humid $\mathrm{CO} 2$ atmosphere. About 
200,000 cells were seeded on 24-well plates for virus titration and neutralisation assays. YFV clinical isolate V-341 (provided by the Laboratorio de Virología, Instituto Nacional de Salud, Bogota) was amplified on Vero cells and titrated in a plaque assay. Briefly, $50 \mathrm{l}$ of serial virus stock dilutions were added to Vero cells in 24-well plates (as previously indicated). The monolayer was overlaid with 450 10.6\% carboxymethylcellulose (Sigma C-4888) in complete DMEM and incubated at $37^{\circ} \mathrm{C}$. Plaques were visualised on day 7 post-infection with $1 \%$ crystal violet staining. Viral titre was $1.8 \mathrm{X} 105 \mathrm{PFU} / \mathrm{ml}$ (7). Plaque reduction neutralisation test (PRNT) for YFV was used for differentiating YFV from DENV infection, according to previous reports. Briefly, serial five-fold serum dilutions (beginning with 1:25) were prepared in DMEM supplemented with 2 $\%$ FBS and added to equal volumes of YFV diluted to yield $20 \mathrm{PFU} / 50 \mathrm{l}$. Virus-serum mixtures were incubated for $1 \mathrm{~h}$ at $37^{\circ} \mathrm{C}$ and three replicates (50 l each) were inoculated into Vero cells in 24-well plates (as previously indicated for viral titration). All samples having a plaque reduction percentage value equal to or greater than $80 \%$ represented a positive assay result according to standard methods (7).

The ultramicro-enzyme-linked immunosorbent assay (UMELISA, TecnoSuma Intl, La Havana) for detecting specific DENV IgM and IgG antibodies is widely used in Colombia for detecting all four DENV serotype IgG and IgM serum antibodies; these assays were carried out following the manufacturer's instructions. This test has been previously evaluated and seen to have $99,4 \%$ sensitivity and $94,8 \%$ specificity.

In brief, serum samples were diluted 1:21 with sample buffer and added to 96-well plates coated with anti-human IgM or IgG antibodies. Unbound antibodies were washed away after 30 minutes' incubation at $37^{\circ} \mathrm{C}$ and a DENV 1 to 4 antigen mixture was then added to the plates; a biotinylated monoclonal antibody against DENV and a phosphatase-streptavidin conjugate was also added. Plates were washed and incubated with 4-metylumbelliferyl phosphate at room temperature. A PK521 fluorometer reader (TecnoSuma) was used for measuring the fluorescence signal. The results were expressed in fluorescence units (FU). A 0.225 fluorescence intensity cut-off point was used for determining positive samples. Parallel negative and positive samples were developed, following the manufacturer's recommendations. 


\section{RESULTS}

Twelve out of the 13 (92,8 \%) samples from YF cases were confirmed by PRNT, returning neutralising titres greater than $1 / 10$; only one case (sample 22) had no detectable YFV neutralising antibody, but it did have epidemiological confirmation. Ten out of the 13 samples (76,9\%) were IgG positive and 6 out of 13 (46,2 \%) were IgM positive in the dengue UMELISA assays (Table 1). Only IgM positive samples 26, 27 and 30 were IgG negative, suggesting that these IgM antibodies were cross-reactive antibodies and were not produced by a previous DENV infection.

Dengue UMELISA was carried out on healthy individuals before and after YF vaccination. None of the samples obtained from healthy donors were positive for DENV IgM UMELISA before YF vaccination (recent DENV infections being discarded). However, 8 out of the 19 post-vaccination samples (42,1 \%) were DENV IgM positive (Table 2), demonstrating high YFV IgM antibody cross-reactivity in dengue ELISA. All 19 samples obtained following YFV vaccination contained YFV neutralising antibodies, since most had titres greater than $1 / 625$. Five pre-vaccination samples (samples 38,43,45,49 and 52) were also positive for DENV IgG and for YFV by PRNT (except sample 52), presumably due to a previous sub-clinical disease or contact with DENV (Table 2).

Table 1. YFV-PRNT antibody 80\% neutralisation titres and DENV IgM and IgG UMELISA fluorescence units from patients having YFV infection

\begin{tabular}{cccc}
\hline Sample & PRNT titre & IgM UMELISA & IgG UMELISA \\
\hline 21 & $1 / 100$ & $\mathrm{~N}$ & 7,5 \\
22 & $\mathrm{~N}$ & $\mathrm{~N}$ & 93,4 \\
23 & $\geq 1 / 625$ & $\mathrm{~N}$ & 29,9 \\
24 & $\geq 1 / 625$ & $\mathrm{~N}$ & 23,1 \\
25 & $1 / 23$ & $\mathrm{~N}$ & 50,6 \\
\hline 26 & $\geq 1 / 625$ & 45,4 & $\mathrm{~N}$ \\
27 & $\geq 1 / 625$ & 30,4 & $\mathrm{~N}$ \\
28 & $\geq 1 / 625$ & 120,6 & 189,7 \\
29 & $\geq 1 / 625$ & 182,1 & 189,7 \\
30 & $\geq 1 / 625$ & 14,4 & $\mathrm{~N}$ \\
31 & $1 / 25$ & $\mathrm{~N}$ & 23,6 \\
\hline 32 & $\geq 1 / 625$ & 6,9 & 95,8 \\
\hline 33 & $1 / 125$ & $\mathrm{~N}$ & 68,4 \\
\hline
\end{tabular}

YFV, yellow fever virus; PRNT, plaque reduction neutralisation test; DENV, dengue virus; UMELISA, ultramicro enzyme-linked immunoabsorbent assay. Antibody titre is a serum dilution causing $80 \%$ or greater plaque reduction; * UMELISA value corresponds to mean fluorescence intensity (MFI); N: negative result for PRNT or UMELISA assay. 
Table 2. YFV-PRNT antibody $80 \%$ neutralisation titres and DENV IgM and IgG UMELISA results for sera from healthy volunteers pre-and post-vaccination with 17D YFV

\begin{tabular}{|c|c|c|c|c|c|c|}
\hline & \multicolumn{2}{|c|}{ PRNT titre } & \multicolumn{2}{|c|}{ IgM UMELISA* } & \multicolumn{2}{|c|}{ IgG UMELISA* } \\
\hline Sample & $\begin{array}{c}\text { Pre- } \\
\text { vaccination }\end{array}$ & $\begin{array}{c}\text { Post- } \\
\text { vaccination }\end{array}$ & $\begin{array}{c}\text { Pre- } \\
\text { vaccination }\end{array}$ & $\begin{array}{c}\text { Post- } \\
\text { vaccination }\end{array}$ & $\begin{array}{c}\text { Pre- } \\
\text { vaccination }\end{array}$ & $\begin{array}{c}\text { Post- } \\
\text { vaccination }\end{array}$ \\
\hline 34 & $\mathrm{~N}$ & $\geq 1 / 625$ & $\mathrm{~N}$ & $\mathrm{~N}$ & $\mathrm{~N}$ & $\mathrm{~N}$ \\
\hline 35 & $\mathrm{~N}$ & $\geq 1 / 625$ & $\mathrm{~N}$ & $\mathrm{~N}$ & $\mathrm{~N}$ & $\mathrm{~N}$ \\
\hline 36 & $\mathrm{~N}$ & $\geq 1 / 625$ & $\mathrm{~N}$ & 31,1 & $\mathrm{~N}$ & $\mathrm{~N}$ \\
\hline 37 & $\mathrm{~N}$ & $1 / 25$ & $\mathrm{~N}$ & $\mathrm{~N}$ & $\mathrm{~N}$ & $\mathrm{~N}$ \\
\hline 38 & $1 / 12$ & $\geq 1 / 625$ & $\mathrm{~N}$ & 0,46 & 5,8 & 5,5 \\
\hline 39 & $\mathrm{~N}$ & $\geq 1 / 625$ & $\mathrm{~N}$ & $\mathrm{~N}$ & $\mathrm{~N}$ & $\mathrm{~N}$ \\
\hline 40 & $\mathrm{~N}$ & $\geq 1 / 625$ & $\mathrm{~N}$ & 21,9 & $\mathrm{~N}$ & $\mathrm{~N}$ \\
\hline 41 & $\mathrm{~N}$ & $\geq 1 / 625$ & $\mathrm{~N}$ & $\mathrm{~N}$ & $\mathrm{~N}$ & $\mathrm{~N}$ \\
\hline 42 & $\mathrm{~N}$ & $\geq 1 / 625$ & $\mathrm{~N}$ & 36,5 & $\mathrm{~N}$ & $\mathrm{~N}$ \\
\hline 43 & $1 / 46$ & $\geq 1 / 625$ & $\mathrm{~N}$ & $\mathrm{~N}$ & 3,9 & 2,4 \\
\hline 44 & $\mathrm{~N}$ & $\geq 1 / 625$ & $\mathrm{~N}$ & $\mathrm{~N}$ & $\mathrm{~N}$ & $\mathrm{~N}$ \\
\hline 45 & $1 / 33$ & $\geq 1 / 625$ & $\mathrm{~N}$ & 180,7 & 110,8 & 189,2 \\
\hline 46 & $\mathrm{~N}$ & $\geq 1 / 625$ & $\mathrm{~N}$ & 63,3 & $\mathrm{~N}$ & $\mathrm{~N}$ \\
\hline 47 & $\mathrm{~N}$ & $\geq 1 / 625$ & $\mathrm{~N}$ & $\mathrm{~N}$ & $\mathrm{~N}$ & $\mathrm{~N}$ \\
\hline 48 & $\mathrm{~N}$ & $\geq 1 / 625$ & $\mathrm{~N}$ & 8,2 & $\mathrm{~N}$ & $\mathrm{~N}$ \\
\hline 49 & $1 / 25$ & $\geq 1 / 625$ & $\mathrm{~N}$ & $\mathrm{~N}$ & 94,7 & 189,2 \\
\hline 50 & $\mathrm{~N}$ & $\geq 1 / 625$ & $\mathrm{~N}$ & 18,4 & $\mathrm{~N}$ & $\mathrm{~N}$ \\
\hline 51 & $\mathrm{~N}$ & $\geq 1 / 625$ & $\mathrm{~N}$ & $\mathrm{~N}$ & $\mathrm{~N}$ & 172,9 \\
\hline 52 & $\mathrm{~N}$ & $\geq 1 / 625$ & $\mathrm{~N}$ & $\mathrm{~N}$ & 4,7 & 22,7 \\
\hline
\end{tabular}

YFV, yellow fever virus; PRNT, plaque reduction neutralisation test; DENV, dengue virus; UMELISA, ultramicro enzyme-linked immunoabsorbent assay; * UMELISA value corresponds to mean fluorescence intensity (MFI); N: negative result for PRNT or UMELISA assay.

All samples from dengue patients were IgM positive (Table 3), having high serum antibody concentrations, thereby demonstrating UMELISA sensitivity and specificity (excluding non-DENV flavivirus sera). $85 \%$ of the samples were also IgG positive and $85 \%$ produced YFV plaque neutralisation, having titres greater than 1/625. PRNT has been proposed as the assay of choice for differentiating DENV and YFV infections. It has been widely used as a specific assay in epidemiological surveillance studies for YFV in different countries having several endemic flaviviruses (including DENV) and has also been used for evaluating host immune response against YF vaccine (8).

Neutralisation titres in 92,3 \% of YF patients were greater than 1/125 and $100 \%$ of post-vaccination samples from healthy volunteers were also PRNT positive (Table 2). Most of the samples from dengue patients (85\%) had neutralising antibodies for YFV, having titres greater than $1 / 625$, a much higher cross-reactive ratio than previously reported. 
Table 3. YFV-PRNT antibody $80 \%$ neutralisation titres and DENV IgM and IgG UMELISA results for sera from patients having DENV infection

\begin{tabular}{cccc}
\hline Sample & PRNT titre & IgM UMELISA* & IgG UMELISA* \\
\hline 1 & $\geq 1 / 625$ & 182,1 & 189,75 \\
2 & $\geq 1 / 625$ & 182,1 & 189,75 \\
3 & $\geq 1 / 625$ & 177,7 & 189,75 \\
4 & $\geq 1 / 625$ & 182,1 & 189,75 \\
5 & $\geq 1 / 625$ & 182,1 & 189,75 \\
6 & $\geq 1 / 625$ & 182,1 & 189,75 \\
\hline 7 & $\geq 1 / 625$ & 132,9 & 189,75 \\
8 & $\mathrm{~N}$ & 182,1 & $\mathrm{~N}$ \\
9 & $\geq 1 / 625$ & 182,1 & 189,75 \\
10 & $\mathrm{~N}$ & 182,1 & 189,75 \\
11 & $\geq 1 / 625$ & 72,5 & 189,75 \\
12 & $\geq 1 / 625$ & 131,9 & 189,75 \\
13 & $\mathrm{~N}$ & 182,1 & $\mathrm{~N}$ \\
14 & $\geq 1 / 625$ & 182,1 & $\mathrm{~N}$ \\
15 & $\geq 1 / 625$ & 182,1 & 189,75 \\
16 & $\geq 1 / 625$ & 94,8 & 189,75 \\
17 & $\mathrm{~N}$ & 182,1 & 4,2 \\
\hline 18 & $\geq 1 / 625$ & 182,1 & 189,75 \\
19 & $\geq 1 / 625$ & 173,4 & 189,75 \\
\hline 20 & $\geq 1 / 625$ & 115,1 & 189,75 \\
\hline
\end{tabular}

YFV, yellow fever virus; PRNT, plaque reduction neutralisation test; DENV, dengue virus; UMELISA, ultramicro enzyme-linked immunoabsorbent assay. N, non-reactive; *UMELISA value corresponds to mean fluorescence intensity (MFI); N: negative result for PRNT or UMELISA assay.

\section{DISCUSSION}

Since the Huila Department of Colombia is likely to have experienced multiple DENV serotype epidemics during the past decades, it may be that YFV neutralising antibodies in serum from dengue patients correspond to memory IgG antibodies produced by an "original antigenic sin" phenomenon (9). It is also known that there has been no mass YF vaccination in this area during recent years and that the samples were mainly taken from children aged less than 10. The effect of neutralising antibodies from previous dengue infection on susceptibility to YFV infection is not clear. Cross-protection amongst Flavivirus has been reported in both experimental animals and humans on numerous occasions $(10,11)$.

PRNT for YFV has 100 \% specificity; however, its specificity was only 15 $\%$ in samples from dengue patients from an endemic Colombian region. Since PRNT is used as a confirmatory assay, these results raise important questions for diagnosis in endemic areas having flavivirus co-circulation, considering that dengue and yellow fever can have similar clinical manifestations and histopathological features (12). 
It has been found that, unlike IgG antibodies, YFV IgM antibodies are highly specific regarding other Flavivirus $(3,13)$. Surprisingly, we found that $46,2 \%$ of the samples from yellow fever patients were DENV IgM-positive and 42,1 $\%$ of post-vaccination samples from healthy donors were DENV IgM-positive, thus showing a high percentage of cross-reactivity for YFV IgM antibodies. Moreover, 5 out of the 19 samples from healthy individuals having had YF vaccination showed DENV IgG and 2 out of the 5 had YFV neutralising antibodies, indicating prior contact with DENV and confirming DENV-YFV cross-reactivity. Previous reports have found DENV IgG cross-reactivity to YFV in ELISA tests and it is known that YFV vaccination in humans following DENV infection produces higher antibody titres for both viruses (14).

Since suitable routine DENV and YVF diagnosis and epidemiological surveillance programmes are needed for applying appropriate epidemic control measures, the results obtained here sketch an unfavourable panorama, considering the narrow antigenic and phylogenetic relationships between DENV and YFV $(15,16)$ and current health systems' available resources. Our findings have indicated the importance of considering past YFV vaccination when confirming cases of dengue, especially considering that cross-reactive antibodies produced during flavivirus-caused infections last from 3 to 6 months. Likewise, there is an anamnestic response during sequential and heterotypical secondary infections, accompanied by a sudden rise in antibody titres. However, our data restrict the problem of diagnosis during acute phases of illness. The lack of samples during the convalescent stage did not let us to rule out PNTR being specific in prevalence studies. We conclude that further research should focus on designing novel experimental strategies for flavivirus diagnosis to address the problem of cross-reactivity between viruses from this family. The World Health Organisation's global strategy for dengue prevention and control focuses on strengthening epidemiological surveillance (1); cross-reactivity between flaviviruses thereby represents a serious concern

Acknowledgements. We would like to thank Dr. Harish Padmanabha and Jason Garry for patiently translating, revising the manuscript and making helpful suggestions.

Conflict of interest: None.

\section{REFERENCES}

1. World Health Organisation [Internet]. Geneve. Dengue and dengue haemorrhagic fever. Fact sheet No. 117. Available from: http://www.who.int/mediacentre/factsheets/fs117/en/ Consulted April 2008. 
2. Deubel V, Mouly V, Salaun JJ, Adam C, Diop MM, Digoutte JP. Comparison of the enzyme-linked immunosorbent assay (ELISA) with standard tests used to detect yellow fever virus antibodies. Am J Trop Med Hyg 1983; 32: 565-568.

3. Vazquez S, Valdes O, Pupo M, Delgado I, Alvarez M, Pelegrino JL, Guzmán MG. MAC-ELISAand ELISA inhibition methods for detection of antibodies after yellow fever vaccination. J Virol Meth 2003; 110: 179-184.

4. Calisher CH, Karabatsos N, Dalrymple JM, Shope RE, Porterfield JS, Westaway EG, Brandt WE. Antigenic relationships between flaviviruses as determined by cross-neutralization tests with polyclonal antisera. J Gen Virol 1989; 70: 37-43.

5. Velandia MP. La Fiebre Amarilla y su control. Biomedica 2004; 24: 5-6.

6. Pan American Health Organisation [Internet]. Washington. Number of reported cases of dengue and dengue haemorrhagic fever (DHF), region of the Americas (by country and subregion). Available from: http://www.paho.org/Project.asp=docs_gen Consulted September 2007.

7. Alvarez M, Palacios D, Vázquez S, Delgado I, García S, Morier L, Guzmán MG. Normalización de la técnica de reducción de placa para diferenciar una infección por dengue de una infección por fiebre amarilla. Rev Cub Med Trop 1998; 50: 177-181.

8. Monath TP, Nichols R, Archambault WT, Moore L, Marchesani R, Tian J, Shope RE, Thomas N, Schrader R, Furby D, Bedford P. Comparative safety and immunogenicity of two yellow fever 17D vaccines (ARILVAX and YF-VAX) in a phase III multicenter, double-blind clinical trial. Am J Trop Med Hyg 2002; 66: 533-541.

9. Mongkolsapaya J, Dejnirattisai W, Xu XN, Vasanawathana S, Tangthawornchaikul N, Chairunsri A, Sawasdivorn S, Duangchinda T, Dong T, Rowland-Jones S, Yenchitsomanus PT, McMichael A, Malasit P, Screaton G. Original antigenic sin and apoptosis in the pathogenesis of dengue hemorrhagic fever. Nat Med 2003; 9: 921-927.

10. Price $\mathrm{WH}$, Thind IS. Protection against West Nile virus induced by a previous injection with dengue virus. Am J Epidem 1971; 94: 596-607.

11. Tarr GC, Hammon WM. Cross-protection between group B arboviruses: resistance in mice to Japanese B encephalitis and St. Louis encephalitis viruses induced by Dengue virus immunization. Infect Immun 1974; 9: 909-915.

12. Tesh RB. Viral hemorrhagic fevers of South-America. Biomedica 2002; 22: 287-295.

13. Koraka P, Zeller H, Niedrig M, Osterhaus AD, Groen J. Reactivity of serum samples from patients with a flavivirus infection measured by immunofluorescence assay and ELISA. Microb Infect 2002; 4: 1209-1215.

14. Carey DE, Myers RM, Rodrigues FM. Two episodes of dengue fever caused by types 4 and 1 viruses, in an individual previously immunized against yellow fever. Am J Trop Med Hyg 1965; 14: 448-450.

15. Gaunt MW, Sall AA, de Lamballerie X, Falconar AK, Dzhivanian TI, Gould EA. Phylogenetic relationships of flaviviruses correlate with their epidemiology, disease association and biogeography. J Gen Virol 2001; 82: 1867-1876.

16. Sather GE, Hammon WM. Protection against St. Louis encephalitis and West Nile arboviruses by previous dengue virus (types 1-4) infection. Proc Soc Exp Biol Med 1970; 135: $573-$ 578. 